\title{
Medical History Taking
}

National Cancer Institute

\section{Source}

National Cancer Institute. Medical History Taking. NCI Thesaurus. Code C146918.

The process of gathering information regarding a person's medical history. 